\title{
Relationship of Sedentary Activity and Physical Activity With The Nutritional Status of Students majoring in Public Health, Malang State University
}

\author{
Bella Anggraini \\ Department of Sport Science \\ Faculty of Sport Science State \\ University of Malang \\ Malang, Indonesia \\ Belaanggraini1@gmail.com
}

\author{
Hartati Eko Wardani* \\ Department of Sport Science \\ Faculty of Sport Science State \\ University of Malang \\ Malang, Indonesia \\ hartati.eko.fik@um.ac.id
}

\author{
Farah Paramita* \\ Department of Sport Science \\ Faculty of Sport Science State \\ University of Malang \\ Malang, Indonesia \\ farah.paramita.fik@um.ac.id
}

\begin{abstract}
Technological sophistication in the era of globalization has shifted changes in human lifestyles to be less actively moving so that it affects the occurrence of overweight and obesity. Students are young adults who have a sedental lifestyle because, most of the time is spent doing tasks in front of a computer screen or playing social media, so it affects the nutritional status of students. The sample used was a student majoring in Public Health of Malang State University in the class of 2017-2019 using proportionate stratified random sampling techniques in sample calculations. Data collection is done online through google form using ASAQ instruments for sedentary activity measurement and Short-Form versions of IPAQ instruments for physical activity measurement. The data was analyzed with univariate and bivariate analysis using Spearman Rank test with $\alpha=0.05$. The results of the analysis showed a significant association between sedentary activity and nutritional status with a value of $\rho$ of 0.010 $<\alpha=0.05$, while in physical activity the results of the analysis showed no significant association between physical activity and nutritional status with a value of $0.540>\alpha=0.05$.
\end{abstract}

Keywords - sedentary activity; physical activity; nutritional status.

\section{INTRODUCTION}

Indonesia is a developing country with dual nutrition problems, namely, less nutritional problems and more nutritional problems. Global Nutrition Report data in 2014 showed indonesia was 17 th out of 117 countries that have complex nutritional problems [1]. Factors that cause nutritional problems are direct and indirect factors [2]. Eating intake and infectious diseases are direct factors, while lack of food availability, wrong parenting, and lack of health services and unhealthy environments are indirect factors (Setiawati et al., 2019). These direct and indirect factors cause nutritional problems such as more nutrition caused by diet and lifestyle changes that occur in the era of globalization [3].

Lifestyle changes that occur in the era of globalization lead to sedentary lifestyles that result in an increase in the prevalence of overweight and obesity that occurs due to body fat accumulation caused by lack of physical activity. Physical activity is an external factor that affects the occurrence of overweight and obesity, because $20 \%-50 \%$ of energy is expended through physical activity [4]. At this time obesity has become a global epidemic that not only occurs in developed countries with high levels of food consumption, but can also occur in developing countries [5]. The association of physical activity with the incidence of oveweight and obesity is caused by excess energy that becomes fat stores in the body [6]. In addition, lack of physical activity and high sedentary activity can be a major contributor to the occurrence of degenerative disease problems [7].

In young adults lifestyle changes occur significantly so they are prone to experiencing energy imbalances that result in weight gain [8]. Students are young adults with very low levels of physical activity, due to the dense schedule of lectures that spend most of their time sitting, and staring at the laptop screen to do tasks. This affects the habit of students to do sedentary activities. Sedentary activities increase the amount of time for sedentary or sedentary activities such as sitting, accessing social media, reading, and staring at a computer screen, thereby reducing the amount of time to do physical activity [9]. Screen high time, and low physical activity makes the diet less appropriate, thus affecting nutritional status. This opinion is in line with the results of research Setiawati 
et al., (2019) that there is a significant association between the intensity of social media use and exercise habits, which shows the higher the intensity of social media use, the lower the exercise habits [3].

Sedentary activity is an activity with very low energy expenditure that has an impact on weight gain (overweight) due to energy imbalances that occur in the body. Lack of physical activity causes excess energy in the body so that it becomes fat stores in the body [10]. A person with a sedentary lifestyle is mostly overweight. This is due to a shift in human lifestyle due to technological developments so that a person becomes less active in moving [5]. The risk of obesity in someone with a sedentary lifestyle or less movement is 4.7 times greater than in someone who is actively exercising [11]. This is in line with research conducted by Sartika, 2014 that respondents who do not actively exercise have a risk of obesity by 1.35 times compared to those who actively exercise [12].

Prevalence of obesity at the age of over 18 years continues to increase. Based on data from Basic Health Research (Riskesdas) 2018, the prevalence of obesity in Indonesia at the age of over 18 years is about $21.8 \%$, while in East Java the prevalence of obesity aged over 18 years reaches $22.37 \%$ [13]. At this time the lifestyle of college students tends to behave sedentary and lack exercise, they spend a lot of time sitting doing tasks in front of a laptop screen. In addition, they also spend a lot of time playing social media so that the time that can be used to do physical activity is getting lower. Looking at the importance of physical activity and the impact caused by sedentary activity on health problems, especially in students majoring in Public Health who have a busy lecture schedule, researchers want to examine the relationship of sedentary activity and physical activity with the nutritional status of students majoring in Public Health, Malang State University .

\section{METHODS}

This study is an analytical observational study with a cross sectional design conducted in January - February 2021. The population used in this study is students majoring in Public Health of Malang State University in the class of 2017-2019. The sample used in this study amounted to 75 people taken using proportionate stratified random sampling techniques with inclusion criteria, namely, active students majoring in Public Health class of 20172019, Students aged 18-23 years, willing to be respondents characterized by willingness to sign informed consent, willing to weigh weight using stepped/analog scales, willing to take height measurements, while for exclusion criteria, namely, students who do not know the size of height and weight, and students who take measurements of height and weight exceed from a period of 1 month.

The study analyzed the relationship of independent variables in the form of sedentary activity levels and physical activity levels with dependent variables in the form of nutritional status as measured by Body Mass Index (BMI). Sedentary activity measurements use the ASAQ (Adolescent Sedentary Activity Questionnaire) questionnaire which has a good validity and rehabilitation value of 0.57-0.86. The ASAQ questionnaire identified 3 dimensions of sedentary behavior, namely, type, duration, and frequency, and then the questionnaire results in 7 days were totaled, then on average in one day.

Physical activity measurements using the IPAQ (International Physical Activity Questionnaire) short form questionnaire that has a validity value of 0.33 and consists of 7 questions with 3 behavioral domains that include activities in the study, travel from one place to another, and recreational activities. In this study, the measurement of nutritional status was carried out independently by respondents, because the study was conducted during the Covid-19 pandemic, so that data retrieval could not be done directly by researchers, so it became a limitation in this study. Measurement of weight and height in this study was carried out independently by respondents with the provision of using a step step scale measuring instrument and microtoise or meter. Weight measurements are done using steppe scales placed on a flat or flat surface, make sure the weighing device shows the number "00.00" before weighing the battery on the scales in good condition, and the position of the body in a standing state perpendicular to the foresight. Measurement of height is done by attaching microtoise to the wall, and make sure the number on the microtoise is in the number " 0 " with the position of the body standing upright, the data collection is supervised by researchers online through video calls and done by spreading questionnaires in the form of google form through whatsapp groups in each force.

The data was analyzed using univariate and bivariate analysis. Univariate analysis is used to analyze each variable descriptively, while bivariate analysis is used to see the relationship between independent variables and dependent variables using spearman rank test with the help of SPSS version 23.0. This research has passed the ethics review and received approval from the Health Research Ethics Commission of the Malang Ministry of Health with No. 047/ KEPK-POLKESMA/ 2021. 


\section{RESULTS}

Respondents used in this study as many as 75 students of the Department of Public Health, Malang State University

TABEL I. TRESPONDENTS USED IN THIS STUDY AS MANY AS 75 STUdents OF THE DePartment of Public Health, Malang STATE UNIVERSITY

\begin{tabular}{|c|c|c|c|}
\hline \multicolumn{2}{|l|}{ Variable } & $\mathbf{n}$ & $\%$ \\
\hline \multicolumn{4}{|l|}{ 1. Gender } \\
\hline Male & & 7 & $9,3 \%$ \\
\hline Female & & 68 & $90,7 \%$ \\
\hline \multicolumn{4}{|l|}{ 2. Age } \\
\hline 19 years & & 18 & $24 \%$ \\
\hline 20 years & & 24 & $32 \%$ \\
\hline 21 years & & 20 & $26,7 \%$ \\
\hline 22 years & & 13 & $17,3 \%$ \\
\hline \multicolumn{4}{|l|}{ 3. $\quad$ Class Year } \\
\hline 2017 & & 20 & $26,7 \%$ \\
\hline 2018 & & 21 & $28 \%$ \\
\hline 2019 & & 34 & $45,3 \%$ \\
\hline \multicolumn{4}{|l|}{ 4. Nutritional Status } \\
\hline$\overline{<18,5}$ & Thin & 14 & $18,7 \%$ \\
\hline $18,5-25,0$ & Normal & 54 & $72 \%$ \\
\hline$>25,1$ & Overweight & 7 & $9,3 \%$ \\
\hline
\end{tabular}

Based on the table above it is known that the characteristics of respondents based on gender are mostly women as many as 68 people $(90.7 \%)$, while the male gender as many as 7 people $(9.3 \%)$. The characteristics of respondents based on the most age are 20 years as many as 24 people (32\%), 21 years as many as 20 people $(26.7 \%), 19$ years as many as 18 people $(24 \%)$, and at least 22 years old as many as 13 people $(17.3 \%)$. The characteristics of respondents based on the most generation years are the class of 2019 as many as 34 people (45.3\%), 2018 as many as 21 people (28\%), and the class of 2017 as many as 20 people $(26.7 \%)$. Characteristics of respondents based on the category of nutritional status are the category of thin as many as 14 people (18.7\%), normal as many as 54 people $(72 \%)$, and fat as many as 7 people $(9.3 \%)$. This indicates that most respondents fall into the normal category.

TABEL II. AVERAGE SEDENTARY ACTIVITY DATA

\begin{tabular}{|l|c|c|}
\hline \multicolumn{1}{|c|}{ Type of Activity } & $\begin{array}{c}\text { Average } \\
\text { (minute/days } \\
\text { ) }\end{array}$ & $\begin{array}{c}\text { Standard } \\
\text { Deviation (sd) }\end{array}$ \\
\hline Watch TV & 20,12 & 39,6 \\
\hline Watch (Youtube, dll) & 117 & 78,2 \\
\hline Use computer to play & 8,8 & 16,8 \\
\hline $\begin{array}{l}\text { Doing tasks with a } \\
\text { computer }\end{array}$ & 163,8 & 94,6 \\
\hline $\begin{array}{l}\text { Doing tasks without a } \\
\text { computer }\end{array}$ & 13,3 & 29,5 \\
\hline Reading for pleasure & 23,9 & 36,9 \\
\hline Additional learning & 0,9 & 4,8 \\
\hline Drive & 11,5 & 13,9 \\
\hline Doing a hobby & 38,6 & 43,5 \\
\hline
\end{tabular}

\begin{tabular}{|l|c|c|}
\hline Relax & 129,9 & 76,1 \\
\hline Listening to music & 46,7 & 18,3 \\
\hline
\end{tabular}

Based on the table above it can be known that the lowest sedentary activity of respondents is additional tutoring / learning with an average time of 0.9 minutes / day, and has a standard deviation of 4.8. While the highest sedentary activity is doing tasks using a computer / laptop with an average time of 163.8 minutes / day, and has a standard deviation of 94.6.

TABEL III. TOTAL SEDENTARY ACTIVITY DATA

\begin{tabular}{|c|c|c|}
\hline Sedentary Activity Level & (f) & (\%) \\
\hline Low & 1 & $1,3 \%$ \\
\hline Moderate & 6 & $8 \%$ \\
\hline High & 68 & $90,7 \%$ \\
\hline Total & 75 & $100 \%$ \\
\hline
\end{tabular}

Based on the table above it can be known that respondents with low sedentary activity categories as many as 1 person $(1.3 \%)$, moderate as many as 6 people $(8 \%)$, and high as many as 68 people $(90.7 \%)$. This indicates that most respondents have high sedentary activity.

\section{Bivariate Analysis Results Of Relationship Between Sedentary Activity and Nutritional Status}

TABEL IV. RELATIONSHIP BETWEEN SEDENTARY ACTIVITY AND NUTRITIONAL STATUS

\begin{tabular}{|c|c|c|c|c|c|c|c|c|c|c|}
\hline \multirow{3}{*}{$\begin{array}{c}\text { Sedent } \\
\text { ary } \\
\text { Activit } \\
y\end{array}$} & \multicolumn{6}{|c|}{ Nutritional Status } & \multirow{2}{*}{\multicolumn{2}{|c|}{ Total }} & \multirow[t]{3}{*}{$\mathbf{r}$} & \multirow[t]{3}{*}{$\rho$} \\
\hline & \multicolumn{2}{|c|}{ Thin } & \multicolumn{2}{|c|}{$\begin{array}{c}\text { Norma } \\
1\end{array}$} & \multicolumn{2}{|c|}{$\begin{array}{l}\text { Overw } \\
\text { eight }\end{array}$} & & & & \\
\hline & $\mathrm{n}$ & $\%$ & $\mathrm{n}$ & $\%$ & $\mathrm{n}$ & $\%$ & $\mathrm{n}$ & $\%$ & & \\
\hline Low & 0 & 0 & 1 & $\begin{array}{l}1, \\
3\end{array}$ & 0 & 0 & 1 & $\begin{array}{c}10 \\
0\end{array}$ & $\begin{array}{l}0, \\
29\end{array}$ & $\begin{array}{c}0,0 \\
10\end{array}$ \\
\hline Moderate & 4 & 5,3 & 2 & $\begin{array}{l}2, \\
7\end{array}$ & 0 & 0 & 6 & $\begin{array}{c}10 \\
0\end{array}$ & 5 & \\
\hline High & $\begin{array}{l}1 \\
0\end{array}$ & $\begin{array}{c}13 \\
3\end{array}$ & $\begin{array}{l}5 \\
1\end{array}$ & $\begin{array}{l}6 \\
8\end{array}$ & 7 & $\begin{array}{l}9, \\
4\end{array}$ & $\begin{array}{l}6 \\
8\end{array}$ & $\begin{array}{c}10 \\
0\end{array}$ & & \\
\hline
\end{tabular}

Based on the results of the spearman rank test obtained a value of significance or Sig. (2- tailed) is 0.010 smaller than 0.05 , so it can be concluded there is a significant relationship between sedentary activity variables and nutritional status variables. The correlation coefficient value that appears in the table is 0.295 , so it can be concluded that the relationship between sedentary activity variables and nutrient status variables is sufficient, and is unidirectional which means that if sedentary activity increases then the risk of becoming more nutritional status (overweight) will also increase. The results of this study are in line with research conducted by Pribadi \& Nurhayati, (2018) that there is a significant association between sedentary activity and nutritional status in students of class X MAN Mojokerto City. This is due to the high sedentary activity such as sitting lazily, 
watching TV, and spending time in front of the screen so that students are lazy to move bergerak [10].

Similar research results were also conducted by Arundhana et al., (2016) that there is a relationship of sedentary activity with the incidence of obesity in children in Frater Thamrin Makassar Elementary School [14]. This is because many children who do less physical activity at school and prefer to take advantage of time off to sit around. But this study is not in line with the research conducted by Ubaidilah \& Nurhayati, (2019) that there is no relationship between sedentary activity and nutritional status in students of class VII SMPN 1 Semen Kediri Regency, because high sedentary activity is not only done in students who have more nutritional status, but learners who have thin and normal nutritional status also do high sedentary activities, and when the meal time arrived the student did not immediately eat but was flirting with his sedentary activities, such as playing games, and others [11].

Based on the results of the study, sedentary activities that are the longest and widely done by respondents are activities to do tasks using a computer / laptop with an average duration of 163.8 minutes / day. In this study sedentary activity has a significant association with nutritional status, because during the Covid-19 pandemic community activities are restricted through social distancing and physical distancing voiced by the government to suppress the spread of the virus. So that students do online learning activities and they spend a lot of time in front of the screen. Restrictions on activities outside the home require the community, especially students, to do all their activities from home. This gives rise to new habits that result in increased sedentary activity.

High sedentary activity leads to a small expenditure of energy, thus impacting a person's nutritional status. This is because the nutritional status of overweight is a condition where there is a accumulation of excess body fat characterized by an increase in adipose tissue mass caused by an imbalance between incoming energy and energy that comes out. Adipose tissue is useful for storing body fat that is used as an energy reserve. If the incoming energy exceeds what is needed, there will be an increase in adipose tissue that causes weight gain [15].

TABEL V. TOTAL PHYSICAL ACTIVITY DATA

\begin{tabular}{|c|c|c|}
\hline $\begin{array}{c}\text { Level of } \\
\text { Physical } \\
\text { Activity }\end{array}$ & (f) & $\mathbf{( \% )}$ \\
\hline Low & 18 & $22,7 \%$ \\
\hline Moderate & 49 & $66,6 \%$ \\
\hline High & 8 & $10,7 \%$ \\
\hline Total & $\mathbf{7 5}$ & $\mathbf{1 0 0 \%}$ \\
\hline
\end{tabular}

Based on the table above it can be known that respondents with low physical activity categories as many as 18 people $(22.7 \%)$, while 49 people $(66.6 \%)$, and high 8 people $(10.7 \%)$. This indicates that most of the respondents had moderate physical activity.

\section{Bivariate Analysis Results of The Relationship Between Physical Activity and Nutritional Status}

TABEL VI. RELATIONSHIP BETWEEN PHYSICAL ACTIVITY AND NUTRITIONAL STATUS

\begin{tabular}{|c|c|c|c|c|c|c|c|c|c|c|}
\hline \multirow{3}{*}{$\begin{array}{c}\text { Physica } \\
\text { l } \\
\text { Activit } \\
\text { y }\end{array}$} & \multicolumn{6}{|c|}{ Nutritonal Status } & \multirow{2}{*}{\multicolumn{2}{|c|}{ Total }} & \multirow[t]{3}{*}{$\mathbf{r}$} & \multirow[t]{3}{*}{$\boldsymbol{\rho}$} \\
\hline & \multicolumn{2}{|c|}{ Thin } & \multicolumn{2}{|c|}{ Normal } & \multicolumn{2}{|c|}{$\begin{array}{c}\text { Overw } \\
\text { eight }\end{array}$} & & & & \\
\hline & $\mathrm{n}$ & $\%$ & $\mathrm{n}$ & $\%$ & $\mathrm{n}$ & $\%$ & $\mathrm{~N}$ & $\%$ & & \\
\hline Low & 4 & $\begin{array}{l}5, \\
3\end{array}$ & 10 & $\begin{array}{c}13, \\
4\end{array}$ & 4 & 5,3 & 18 & 100 & - & $\begin{array}{l}0,5 \\
40\end{array}$ \\
\hline $\begin{array}{c}\text { Modera } \\
\mathrm{t}\end{array}$ & 9 & 12 & 36 & 48 & 3 & 4 & 48 & 100 & $\begin{array}{c}07 \\
2\end{array}$ & \\
\hline High & 1 & $\begin{array}{l}1, \\
3\end{array}$ & 8 & $\begin{array}{c}10, \\
7\end{array}$ & 0 & 0 & 9 & 100 & & \\
\hline
\end{tabular}

Based on the results of spearman rank test obtained significant value or Sig. (2-tailed) is 0.540 greater than 0.05 , hence it can be concluded that there is no significant relationship between physical activity variables and nutritional status variables. The value of the correlation coefficient that appears in the table is 0.072 , so it can be concluded that the relationship between physical activity variables and strong nutritional status variables, and is not in the direction which means that if physical activity increases then the risk of becoming a nutritional status will decrease. The results of this study are in line with research conducted by Christianto et al., (2018) that there is no meaningful association between physical activity and the incidence of obesity. This is because the average body mass index of respondents falls into the risk range of overweight or obesity [16]. Another study conducted by Putri, (2016) also showed that there was no meaningful relationship between physical activity and nutritional status, because the participants' activity belonged to light and moderate physical activity [17]. But this study is not in line with research conducted by Roring et al., (2020) which showed there was a significant association between physical activity and nutritional status in respondents. The result of the correlation coefficient is known at 0.358 so this value indicates a moderate level of relationship in the direction of the positive relationship between physical activity and nutritional status [5]. Similar research was also found in the study of Cahyaning et al., (2019) In his research entitled "Relationship between Consumption Patterns, Physical Activity and Pocket Money Amount with Nutritional Status in State Junior High Students in Malang City in 2019", which showed that there is a significant relationship between consumption patterns and physical activity with nutritional status in junior high school students in Malang City. 
In this study there was no association between physical activity and nutritional status, the absence of an association was possible because the factors that affect nutritional status were multifactor while physical activity was only one factor. Another factor that affects nutritional status in addition to physical activity is food intake. Food intake plays an important role in a person's nutritional status, if there is an imbalance between intake and energy expenditure, there will be nutritional problems that affect nutritional status. This opinion is in line with research conducted by Ubro et al., (2014), where based on the results of the analysis obtained the value of the correlation coefficient ( $r$ ) of -0.234 and the value of $p$ of $0.043<\alpha=0.05$ which means that there is a meaningful relationship between energy intake and BMI [18]. The results of another study conducted by Andina Rachmayani et al., (2018) also stated that there is a significant positive relationship between energy intake and nutritional status. Other studies that show similar results have also been conducted by There was no association between physical activity and obesity status in female students [19]. This shows that if there is an increase in energy intake then the risk to become more nutritional status (overweight) will also increase, and vice versa [20].

\section{CONCLUSIONS}

Based on the results of the study, it is necessary to socialize about the importance of physical activity and it is recommended to do moderate intensity physical activity with a duration of 150 minutes / week or 20 minutes / day, as an effort to prevent degenerative diseases. In addition, for further researchers, physical activity measurements are recommended using actigraphy tools or pedometers in order to provide accurate results compared to just using questionnaires.

\section{REFERENCES}

[1] IFPRI. (2014). Actions and Accountability to Accelerate the World's Progress on Nutrition, Washington, DC. In Global Nutrition Report 2014.

[2] Ngoya, M. F. (2015). Mengawal Sustainable Development Goals (SDGs); Meluruskan Orientasi Pembangunan yang Berkeadilan. Sosioreligius, I(1), 77 88.

[3] Setiawati, F. S., Mahmudiono, T., Ramadhani, N., \& Hidayati, K. F. (2019). Intensitas Penggunaan Media Sosial, Kebiasaan Olahraga, dan Obesitas Pada Remaja Di SMA Negeri 6 Surabaya Tahun 2019. Amerta Nutrition, $3(3)$,

142 https://doi.org/10.20473/amnt.v3i3.2019.142-148

[4] Anisa, A. F., Darozat, A., Aliyudin, A., Maharani, A., Fauzan, A. I., Fahmi, B. A., Budiarti, C., N, R. D. F., \& Hamim, E. A. (2017). Permasalahan Gizi Masyarakat Dan Upaya Perbaikannya. Gizi Masyarakat, 40, 1-22.

[5] Roring, N. M., Posangi, J., \& Manampiring, A. E. (2020). Hubungan antara pengetahuan gizi, aktivitas fisik, dan intensitas olahraga dengan status gizi. Jurnal
Biomedik: Jbm, 12(2), 110-116. https://doi.org/10.35790/jbm.12.2.2020.29442

[6] Kusumawardhani, W. (2020). Hubungan Perilaku Diet Dengan Massa Lemak Tubuh Pada Remaja Putri Di SMA Negeri 5 Surabaya The Correlation of Dieting Behavior with Body Fat Mass of Adolescent Girls at Senior High School 5 Surabaya. Amerta Nutrition, 103 108. https://doi.org/10.20473/amnt

[7] Fadila, I. (2016). Relasi perilaku sedentari, gizi lebih dan produktivitas kerja masyarakat perkotaan. Peran MST Dalam Mendukung Urban Lifestyle Yang Berkualitas,

http://repository.ut.ac.id/id/eprint/7087

[8] Widiyatmoko, F., \& Hadi, H. (2018). Tingkat Aktivitas Fisik Siswa Di Kota Semarang. Journal Sport Area, $3(2)$, 140 . https://doi.org/10.25299/sportarea.2018.vol3(2).2245

[9] Thamaria, N. (2017). Penilaia Status Gizi.

[10] Pribadi, \& Nurhayati. (2018). Hubungan Antara Aktivitas Sedentari Dengan Status Gizi Siswa Kelas X Man Kota Mojokerto. Jurnal Pendidikan Olahraga Dan Kesehatan, 6(2), 327-330.

[11] Ubaidilah, M., \& Nurhayati, F. (2019). Hubungan Antara Aktivitas Sedentari Dengan Status Gizi Pada Peserta Didik Kelas VII SMPN 1 Semen Kabupaten Kediri. Jurnal Pendidikan Olahraga Dan Kesehatan, 07(03), 9-12.

[12] Sartika, R. A. D. (2011). Faktor Risiko Obesitas Anak Usia 5-15 tahun di Indonesia. Kesehatan, 15(4), 70-72.

[13] Riskesdas. (2018). Laporan Nasional Riskesdas 2018. In Badan Penelitian dan Pengembangan Kesehatan (p. 198).

http://labdata.litbang.kemkes.go.id/images/download/lap oran/RKD/2018/Laporan_Nasional_RKD2018_FINAL. pdf

[14] Arundhana, A. I., Hadi, H., \& Julia, M. (2016). Perilaku sedentari sebagai faktor risiko kejadian obesitas pada anak sekolah dasar di Kota Yogyakarta dan Kabupaten Bantul. Jurnal Gizi Dan Dietetik Indonesia (Indonesian Journal of Nutrition and Dietetics), 1(2), 71. https://doi.org/10.21927/ijnd.2013.1(2).71-80

[15] Cahyaning, R. C. D., Supriyadi, \& Kurniawan, A (2019). Hubungan Pola Konsumsi , Aktivitas Fisik dan Jumlah Uang Saku dengan Status Gizi pada Siswa SMP Negeri di Kota Malang Tahun 2019. Sport Science and Health, 1(1), 22-27. http://journal2.um.ac.id/index.php/jfik/article/download/ 9984/4488

[16] Christianto, D. A., Barus, A. M. B., Dewita, A. N., Ramadhanti, Puspitasari, A. R., Pramudito, P. A., \& Fenty. (2018). Hubungan Aktivitas Fisik Terhadap Kejadian Obesitas Berdasarkan Indeks Massa Tubuh Di Desa Banjaroyo Kulon Progo Daerah Istimewa Yogyakarta. Berkala Ilmiah Kedokteran Duta Wacana, 3(2), 78-88.

[17] Putri, C. (2016). Hubungan Asupan Energi Dan Aktivitas Fisik Dengan Status Gizi Siswa-Siswi Smp Muhammadiyah 1 Surakarta Disusun sebagai salah satu syarat menyelesaikan Program Studi Strata I.

[18] Ubro, I. (2014). Hubungan Antara Asupan Energi Dengan Status Gizi Mahasiswa Program Studi Pendidikan Dokter Angkatan 2013 Fakultas Kedokteran Universitas Sam Ratulangi. Jurnal E-Biomedik, 2(1). https://doi.org/10.35790/ebm.2.1.2014.3753

[19] Yuliana, \& Winarno, M. E. (2020). Hubungan Aktivitas Fisik dan Pola Makan Terhadap Status Obesitas Pada Siswa Sekolah Menengah Pertama. Sport Science and $\begin{array}{lll}\text { Health, } & 2(6), & 301-311 .\end{array}$ http://journal2.um.ac.id/index.php/jfik/article/view/1172 9

[20] Andina Rachmayani, S., Kuswari, M., \& Melani, V. (2018). Hubungan Asupan Zat Gizi dan Status Gizi Remaja Putri di SMK Ciawi Bogor. Indonesian Journal of Human Nutrition, 5(2), 125-130.[1] https://doi.org/10.21776/ub.ijhn.2018.005.02.6 